\title{
Ectopic tooth in the orbital floor: an unusual case of dentigerous cyst
}

\author{
Janardan B Garde, Adwait Uday Kulkarni, Dattaprasad P Dadhe \\ Oral and Maxillofacial Surgery Department, Sinhgad Dental College and Hospital, Pune, Maharashtra, India
}

Correspondence to Dr Adwait Uday Kulkarni, dradwaitkulkarni@gmail.com

\section{DESCRIPTION}

Dentigerous cysts surrounding impacted teeth often displace these teeth into ectopic positions. In maxilla, these teeth are often displaced into the sinus sometimes even to the level of floor of orbit. By illustrating this case we would like to emphasise the importance of a thorough imaging for any unaccounted missing tooth associated with vague symptoms like sinusitis or visual disturbances. ${ }^{12}$ A 19 -yearold male patient reported with a vague pain on the right side of face which was throbbing in nature and radiating to the eye on the same side since 15 months. The patient gave no positive medical or family history. He reported transient diplopia in upward gaze occasionally. On examination, tenderness was revealed over the right malar region. Intraorally, there was missing maxillary right third molar. The second molar had been extracted for the same complaint a year back. Crepititions were palpated over the canine fossa region giving an impression of cystic lesion. Aspiration yielded straw coloured fluid. Surprisingly no symptoms of sinusitis were present. The patient's orthopantomogram revealed a high posterior impacted third molar in the maxilla. To ascertain the position further, a CT scan was undertaken to ascertain the location, extent and access of the pathology (figures 1 and 2). The patient was operated for excisional biopsy of the cyst along with extraction of the involved molar via the Caldwel Luc approach under general anesthesia. Postoperative recovery was uneventful. Histopathology of the excised specimen confirmed dentigerous cyst while ruling out kerocystic, amelobleastic and malignant changes.

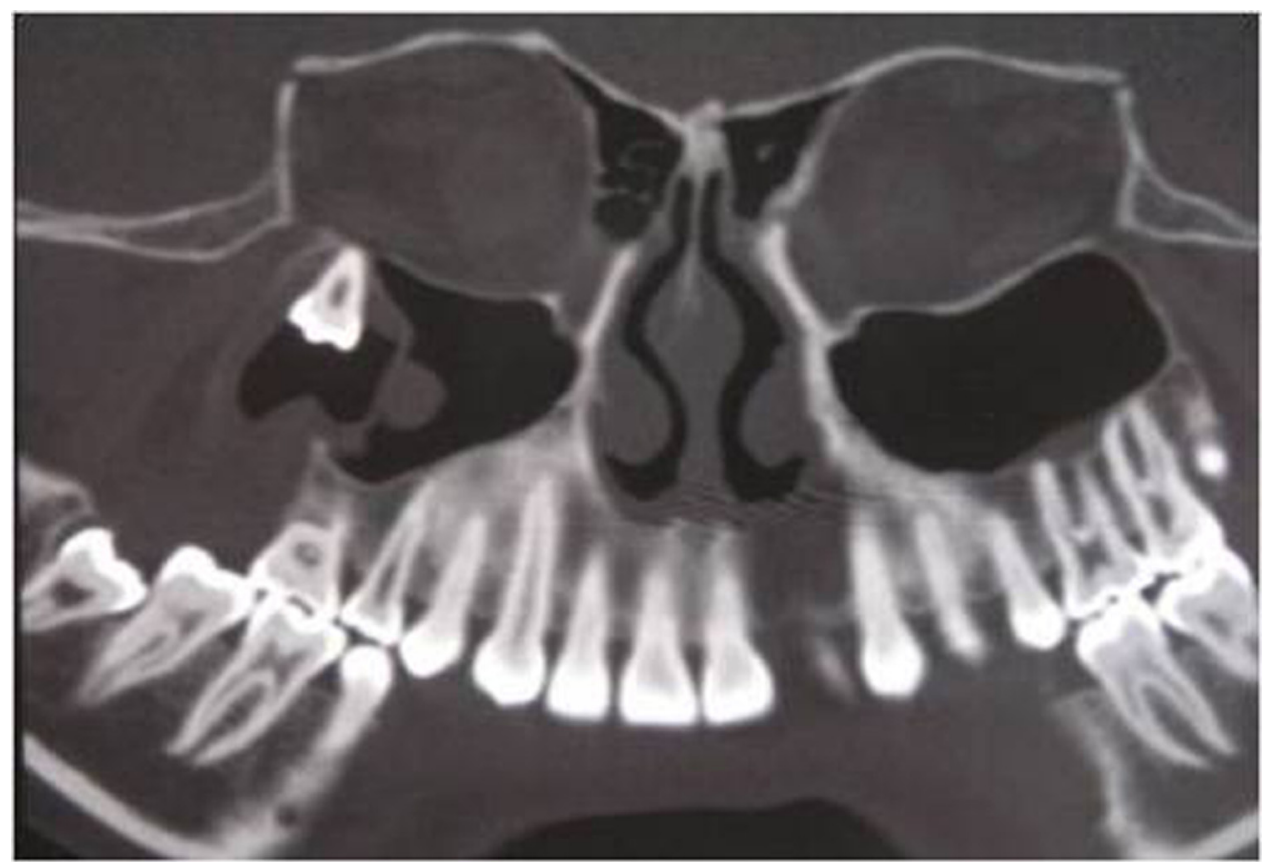

Figure 1 Coronal section CT scan showing posterosuperior position of the ectopic tooth with the dentigerous cyst encompassing the entire maxillary sinus on the right side. 


\section{BMJ Case Reports}

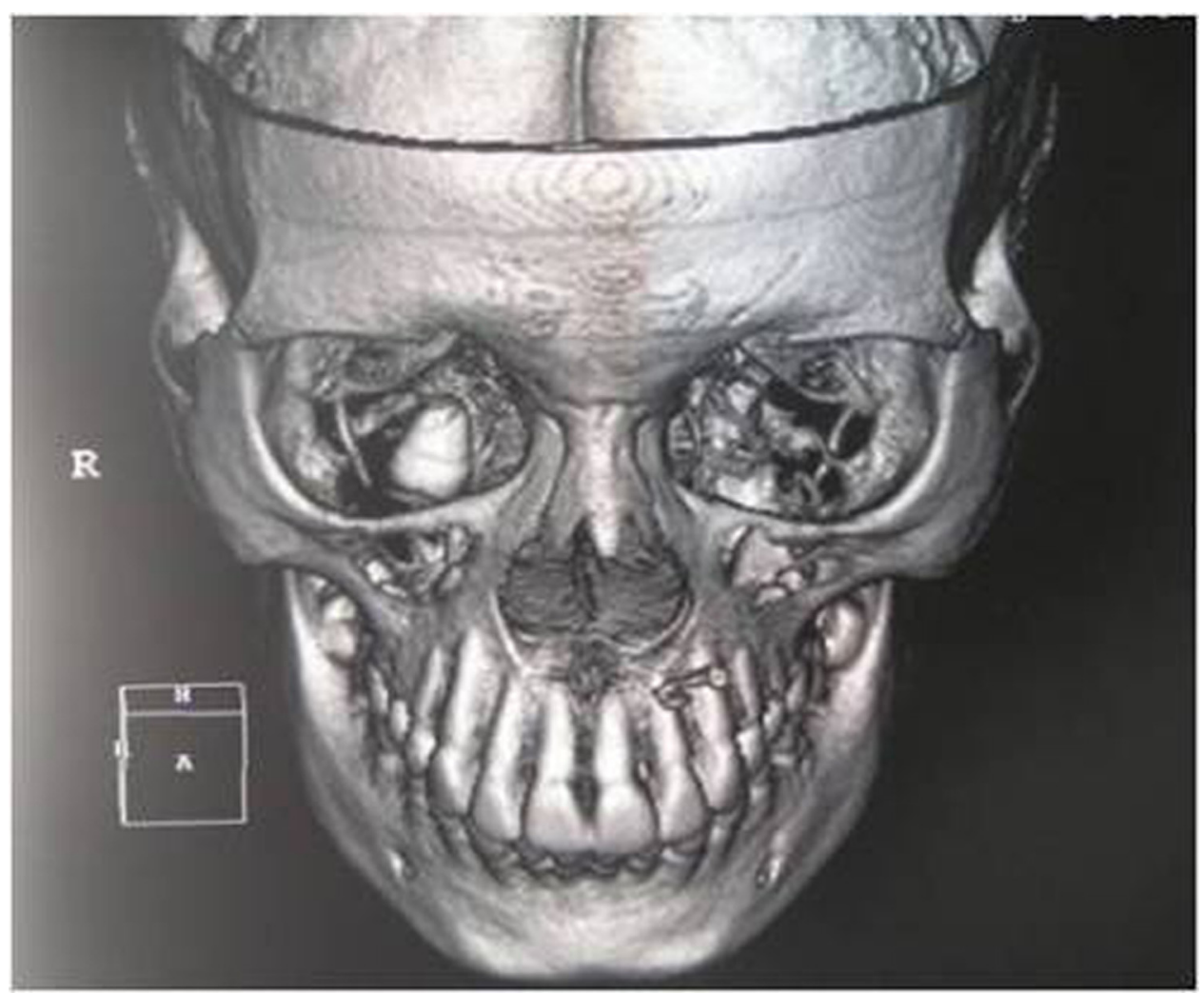

Figure $23-D$ reconstruction of the CT scan shows involvement of the orbital floor.

Competing interests None.

Patient consent Obtained.

\section{REFERENCES}

1. Litvin M, Caprice D, Infranco L. Dentigerous cyst of the maxilla with impacted tooth displaced into orbital rim and floor. Ear Nose Throat J 2008;87:160-2.

2. Beriat GK, Beriat NC, Yasinkaya E. Ectopic molar tooth in the maxillary sinus: a case report. Clin Dent Res 2011;35:35-40.

This pdf has been created automatically from the final edited text and images.

Copyright 2012 BMJ Publishing Group. All rights reserved. For permission to reuse any of this content visit

http://group.bmi.com/group/rights-licensing/permissions.

BMJ Case Report Fellows may re-use this article for personal use and teaching without any further permission.

Please cite this article as follows (you will need to access the article online to obtain the date of publication).

Garde JB, Kulkarni AU, Dadhe DP. Ectopic tooth in the orbital floor: an unusual case of dentigerous cyst. BMJ Case Reports 2012; 10.1136/bcr.11.2011.5266, Published XXX

Become a Fellow of BMJ Case Reports today and you can:

- Submit as many cases as you like

- Enjoy fast sympathetic peer review and rapid publication of accepted articles

- Access all the published articles

- Re-use any of the published material for personal use and teaching without further permission

For information on Institutional Fellowships contact consortiasales@bmjgroup.com

Visit casereports.bmj.com for more articles like this and to become a Fellow 